\title{
MENINGKATKAN AKTIVITAS BELAJAR SISWA MELALUI MODEL PEMBELAJARAN KOOPERATIF TIPE TAI PADA PELAJARAN MATEMATIKA KELAS V SDN 104204 SAMBIREJO TIMUR
}

\author{
Wiwik Suryati \\ Surel: smtp_elang82@yahoo.co.id
}

\begin{abstract}
ABSTRAK
Penelitian ini bertujuan untuk meningkatkan aktivitas belajar siswa dengan model pembelajaran Kooperatif Tipe TAI. Subjek penelitian ini adalah siswa kelas V SD Negeri 104204 Sambirejo Timur yang berjumlah 34 orang sedangkan objek penelitian ini adalah aktivitas belajar siswa pada pelajaran Matematika dengan menggunakan model pembelajaran Kooperatif Tipe TAI. Pada siklus I pertemuan II siswa yang aktif meningkat yaitu ada 18 orang siswa dengan persentasi 52,94\% sedangkan siswa yang tidak aktif ada 16 siswa dengan persentasi 47,06\%. Pada siklus II pertemuan I siswa yang aktif adalah 33 siswa dengan persentasi 97,05\% sedangkan siswa yang tidak aktif hanya 1 orang siswa dengan persentasi $2,94 \%$. Kemudian meningkat pada siklus II pertemuan II dengan persentasi $100 \%$ dan tidak ditemukan lagi siswa yang menunjukkan aktivitas rendah.
\end{abstract}

Kata Kunci: Hasil Belajar, Kooperatif, Tipe TAI

\section{PENDAHULUAN}

Matematika merupakan ilmu universal yang mendasari perkembangan teknologi modern yang mempunyai peran penting dalam berbagai disiplin ilmu dan memajukan daya pikir manusia. Sehingga tidak mengherankan jika mata pelajaran Matematika diberikan kepada semua peserta didik mulai dari sekolah dasar hingga perguruan tinggi. Hal ini dimaksudkan untuk membekali peserta didik dengan kemampuan berpikir logis, analitis, sistematis, kritis, dan kreatif, serta kemampuan bekerjasama untuk bertahan hidup pada keadaan yang selalu berubah, tidak pasti dan kompetitif.

Dengan demikian, ilmu pengetahuan dan teknologi menjadi sebuah kebutuhan setiap individu. Setiap siswa harus mendapatkan bekal pendidikan yang berkualitas untuk meningkatkan kemampuan diri. Oleh karena itu, mutu pendidikan di dalam persekolahan harus ditingkatkan. Model pembelajaran adalah kerangka konseptual yang melukiskan prosedur yang sistematis dalam mengorganisasikan pengalaman belajar untuk mencapai tujuan belajar tertentu, dan berfungsi sebagai pedoman bagi para perancang pembelajaran dan para pengajar 
dalam merencanakan aktivitas belajar mengajar. Dengan demikian aktivitas pembelajaran benar-benar merupakan kegiatan yang bertujuan dan tertata secara sistematis dan diharapkan akan membantu peserta didik sedemikian rupa sehingga tujuan pembelajaran tercapai.

Guru adalah orang yang tahu persis situasi dan kondisi diterapkannya kurikulum yang berlaku. Selain itu, guru bertanggung jawab atas terciptanya hasil belajar yang diinginkan dan berperan dalam terciptanya proses pembelajaran yang dapat mengantarkan siswa ke tujuan pembelajaran yang telah ditetapkan. Sehingga guru harus memahami bahwa kemampuan siswa berbedabeda, serta tidak semua siswa menyenangi mata pelajaran matematika. Jadi dalam memilih suatu model pembelajaran, guru harus memiliki pertimbangan-pertimbangan yang tepat agar tujuan pembelajaran yang telah ditetapkan dapat tercapai.

Berdasarkan observasi yang dilakukan penulis di SDN 104204 Sambirejo Timur diperoleh keterangan bahwa aktivitas dan hasil belajar matematika siswa di kelas $\mathrm{V}$ SD masih tergolong rendah. Hal ini sejalan dengan ketidakmampuan guru memilih metode pembelajaran yang tepat akibatnya aktivitas yang terjadi di dalam kelas masih berpusat dan didominasi oleh guru. Guru menyampaikan materi menggunakan metode ceramah, yaitu dengan menerangkan konsep dan operasi matematika kemudian memberikan latihan soal. Sehingga aktivitas siswa hanya terbatas dalam hal mendengarkan dan mengerjakan soal sesuai perintah guru. Akhirnya siswa menganggap matematika sebagai mata pelajaran yang sulit dan tidak menyenangkan. Mata pelajaran yang tidak bisa lepas dari keterampilan berhitung ini seringkali dihindari. Bahkan karena merasa kesulitan mengerjakan soal matematika, terdapat siswa yang berbicara dengan teman di luar materi pelajaran, atau mengerjakan soal tidak sungguhsungguh. Hal ini juga disebabkan oleh ketidakmampuan guru untuk memperhatikan perbedaan setiap individu dalam kelas sehingga tidak ada kesempatan siswa yang berkemampuan lebih untuk membantu siswa yang berkemampuan kurang. Jika proses pembelajaran yang demikian terus terjadi maka dapat mempengaruhi hasil belajarnya menjadi rendah. Padahal untuk meningkatkan hasil belajar matematika, pengajarannya dimulai sejak dini, yakni mulai dari sekolah dasar yang nantinya digunakan sebagai landasan untuk jenjang yang lebih tinggi.

Tujuan pembelajaran dapat menentukan suatu strategi yang harus digunakan guru. Hal ini sering dilupakan guru. Guru yang senang berceramah, hampir setiap tujuan menggunakan strategi penyampaian, 
seakan-akan dia bepikir bahwa segala jenis tujuan dapat dicapai dengan strategi yang demikan. Hal ini tentu saja keliru. Apabila kita menginginkan siswa terampil menggunakan alat tertentu, katakanlah terampil menggunakan thermometer sebagai alat pengukur suhu badan, tidak mungkin menggunakan strategi penyampaian (bertutur). Untuk mencapai tujuan yang demikian, siswa harus berpraktik secara langsung. Sehingga apa yang diharapkan dapat terwujud.

Untuk

mewujudkan

pembelajaran yang menyenangkan peneliti tertarik menggunakan mode pembelajaran kooperatif tipe TAI karena menjanjikan hasil optimal dengan alasan bahwa salah satu model pembelajaran yang melibatkan siswa secara individu dan menuntut siswa belajar aktif di dalam kelompok adalah dengan menerapkan model pembelajaran Kooperatif tipe TAI. Pembelajaran dengan menggunakan TAI adalah pembelajaran yang menggabungkan pembelajaran individual dengan pembelajaran kelompok. Pembelajaran yang dilakukan dengan kerja sama kelompok heterogen dapat membantu siswa apabila mengalami kesulitan dalam menguasai materi pelajaran, sehingga peran anggota kelompok juga besar dalam meningkatkan hasil belajar matematika anggota yang lainnya.
Untuk meraih tujuan personel mereka, anggota kelompok harus membantu teman satu timnya untuk melakukan apapun guna membuat kelompok mereka berhasil dan yang lebih penting, mendorong anggota satu kelompoknya untuk melakukan usaha maksimal. Dengan menerapkan model pembelajaran tipe TAI, diharapkan dapat meningkatkan aktivitas belajar matematika siswa. Dengan siswa mempunyai kebebasan untuk bertindak, aktif berdiskusi, saling memberikan informasi untuk memahami suatu konsep, dan saling membantu dalam memahami materimateri yang diajarkan diharapkan supaya aktivitas belajar matematika meningkat.

Berdasarkan uraian diatas peneliti menentukan judul "Meningkatkan Aktivitas Belajar Siswa Melalui Model Pembelajaran Kooperatif Tipe TAI Pada Pelajaran Matematika Siswa Kelas V SDN 104204 Sambirejo Timur TA. 2017/2018".

Tujuan penelitian merupakan bagian yang terpenting dari suatu penelitian karena akan menentukan arah dari hasil penelitian secara terperinci. Berdasarkan permasalahan di atas, penelitian ini bertujuan untuk meningkatkan aktivitas belajar siswa melalui model pembelajaran Kooperatif tipe TAI pada pelajaran matematika siswa kelas $\mathrm{V}$ SDN 
104204 Sambirejo Timur TA.2017/2018.

\section{METODE PENELITIAN}

Pada penelitian ini, peneliti menggunakan jenis penelitian tindakan kelas (PTK) yang mengarah kepada penggunaan model pembelajaran kooperatif tipe TAI dalam meningkatkan aktivitas belajar siswa pada materi pokok Perbandingan di kelas V Semester II SDn 104204 Sambirejo Timur Tahun ajaran 2017/2018.

Penelitian ini bertujuan untuk meningkatkan aktivitas belajar siswa dengan model pembelajaran Kooperatif Tipe TAI. Subjek penelitian ini adalah siswa kelas V SD Negeri 104204 Sambirejo Timur yang berjumlah 34 orang sedangkan objek penelitian ini adalah aktivitas belajar siswa pada pelajaran Matematika dengan menggunakan model pembelajaran Kooperatif tipe TAI.

\section{HASIL DAN PEMBAHASAN}

Pada tahap ini kegiatan yang dilakukan peneliti adalah melaksanakan pembelajaran dengan skenario pembelajaran yang telah disusun dengan memperhatikan tindakan yang akan diterapkan yang mengarah pada model pembelajaran kooperatif tipe TAI. Aktivitas belajar siswa siklus I dapat dilihat pada gambar dibawah ini:

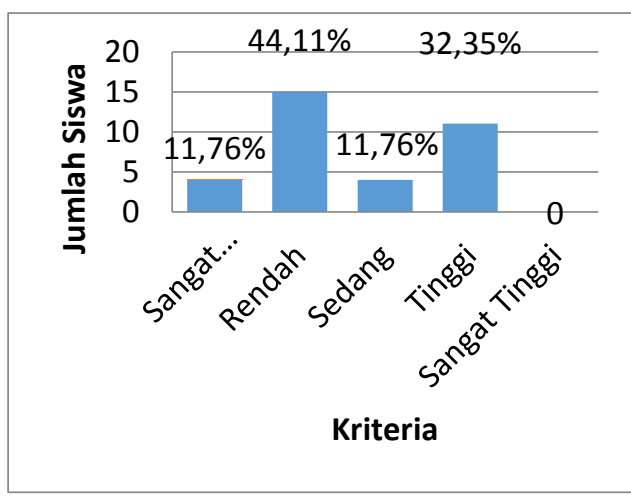

Gambar 1. Aktivitas Belajar Siswa Siklus I

Gambar di atas, terlihat bahwa setelah dilakukan proses pembelajaran pada siklus I aktivitas belajar siswa yang terdiri dari 34 jumlah siswa di kelas $\mathrm{V}$ terdapat 4 siswa yang memperoleh kriteria sangat rendah dengan nilai rata-rata $11,76 \%$, dan terdapat 15 siswa yang memperoleh kriteria aktvitas rendah dengan nilai rata-rata $44,11 \%$, dan terdapat 4 siswa yang memperoleh kriteria aktivitas sedang dengan nilai rata-rata $11,76 \%$, dan terdapat 11 siswa yang memperoleh kriteria aktivitas tinggi dengan nilai rata-rata $32,35 \%$.

Berikut ini adalah hasil observasi aktivitas belajar siswa pada siklus II:

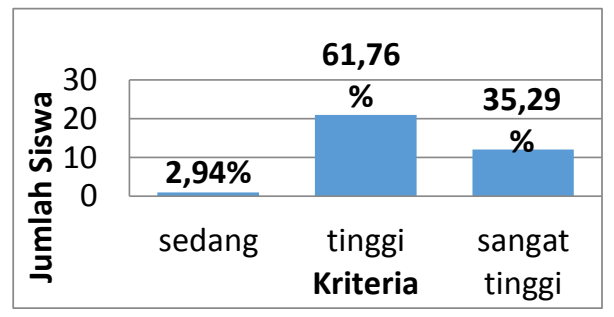

Gambar 2. Aktivitas Belajar Siswa Siklus II 
Dari gambar di atas, terlihat bahwa setelah dilakukan proses pembelajaran pada siklus I pertemuan II aktivitas belajar siswa yang terdiri dari 34 jumlah siswa di kelas $\mathrm{V}$ terdapat 1 siswa yang memperoleh kriteria sedang dengan nilai rata-rata $2,94 \%$, dan terdapat 21 siswa yang memperoleh kriteria aktivitas tinggi dengan nilai rata-rata $61,76 \%$, dan terdapat 12 siswa yang memperoleh kriteria aktivitas sangat tinggi dengan nilai rata-rata $35,29 \%$.

\section{Pembahasan}

Setelah melakukan 2 siklus penelitian dengan menggunakan model pembelajaran kooperatif tipe TAI dalam pelajaran Matematika, telah terbukti adanya peningkatan yang terjadi terhadap aktivitas belajar siswa kelas $\mathrm{V}$ yang dapat dilihat baik secara individual maupun klasikal.

Terlihat bahwa setelah dilakukan proses pembelajaran pada siklus I pertemuan I aktivitas belajar siswa yang terdiri dari 34 jumlah siswa di kelas $\mathrm{V}$ terdapat 4 siswa yang memperoleh kriteria sangat rendah dengan nilai rata-rata $11,76 \%$, dan terdapat 15 siswa yang memperoleh kriteria aktvitas rendah dengan nilai rata-rata $44,11 \%$, dan terdapat 4 siswa yang memperoleh kriteria aktivitas sedang dengan nilai rata-rata $11,76 \%$, dan terdapat 11 siswa yang memperoleh kriteria aktivitas tinggi dengan nilai rata-rata
32,35\%. Secara klasikal Persentasi siswa yang aktif adalah 11 orang dengan nilai rata-rata $32,35 \%$. Sedangkan siswa yang tidak aktif secara klasikal terdapat 23 orang siswa dengan nilai rata-rata $67,64 \%$. Observasi kegiatan guru dalam pembelajaran memperoleh nilai $66,25 \%$ (artinya guru tidak berhasil menggunakan model pembelajaran tipe TAI).

Pada siklus I pertemuan II aktivitas belajar siswa yang terdiri dari 34 jumlah siswa di kelas $\mathrm{V}$ terdapat 1 siswa yang memperoleh kriteria sangat rendah dengan nilai rata-rata $2,94 \%$, dan terdapat 1 siswa yang memperoleh kriteria aktivitas rendah dengan nilai rata-rata $2,94 \%$, dan terdapat 14 siswa yang memperoleh kriteria aktivitas sedang dengan nilai rata-rata $41,17 \%$ dan terdapat 12 siswa yang memperoleh kriteria aktivitas tinggi dengan nilai rata-rata 35,29\%. Dan terdapat 6 siswa yang memperoleh kriteria aktivitas sangat tinggi dengan nilai rata-rata $17,64 \%$. Secara klasikal Persentasi siswa yang aktif ada 18 orang dengan nilai rata-rata $52,94 \%$. Sedangkan siswa yang tidak aktif secara klasikal terdapat 16 siswa nilai rata-rata $47,06 \%$. Dapat disimpulkan aktivitas siklus I pertemuan II tergolong baik hal ini sejalan dengan perolehan nilai pada kegiatan guru dengan nilai $78,75 \%$ (kriteria baik), 
guru berhasil menggunakan model pembelajaran kooperatif tipe TAI.

Pada siklus II pertemuan I aktivitas belajar siswa yang terdiri dari 34 jumlah siswa di kelas V terdapat 1 siswa yang memperoleh kriteria sedang dengan nilai rata-rata $2,94 \%$, dan terdapat 21 siswa yang memperoleh kriteria aktivitas tinggi dengan nilai rata-rata $61,76 \%$, dan terdapat 12 siswa yang memperoleh kriteria aktivitas sangat tinggi dengan nilai rata-rata $35,29 \%$. Secara klasikal Persentasi siswa yang aktif adalah 33 siswa dengan nilai rata-rata $97,05 \%$. Sedangkan siswa yang tidak aktif secara klasikal hanya 1 siswa dengan nilai rata-rata $2,94 \%$. Observasi terhadap kegiatan guru juga dikategorikan berhasil yaitu dengan nilai rata-rata $87,5 \%$ (kategori sangat baik).

Pada siklus II pertemuan II aktivitas belajar siswa yang terdiri dari 34 jumlah siswa di kelas V terdapat 18 siswa yang memperoleh kriteria aktivitas tinggi dengan nilai rata-rata $52,94 \%$, dan terdapat 16 siswa yang memperoleh kriteria aktivitas sangat tinggi dengan nilai rata-rata $47,05 \%$. Secara klasikal pada siklus II pertemuan II sudah aktif dengan nilai rata-rata $100 \%$ dan tidak ditemukan lagi siswa yang menunjukkan aktivitas rendah. Observasi terhadap kegiatan guru juga dikategorikan berhasil yaitu dengan nilai rata-rata $93,75 \%$ (kategori sangat baik).

\section{SIMPULAN}

Berdasarkan hasil penelitian yang telah dilakukan pada siklus I dan II, maka diperoleh kesimpulan bahwa dengan menerapkan model pembelajaran kooperatif tipe TAI dapat meningkatkan aktivitas belajar siswa pada pelajaran Matematika kelas V SD Negeri 104204 Sambirejo Timur tahun ajaran 2017/2018. Presentase siswa yang termotivasi pada siklus I pertemuan I yaitu $32,35 \%$ kemudian meningkat pada siklus I pertemuan II yaitu $52,94 \%$, pada siklus II pertemuan I meningkat menjadi $97,05 \%$ dan pada siklus II pertemuan II meningkat menjadi $100 \%$.

Upaya yang dilakukan peneliti untuk meningkatkan aktivitas belajar siswa pada pelajaran Matematika yaitu dengan menerapkan model pembelajaran kooperatif tipe TAI yaitu dengan membimbing siswa belajar secara individu dengan bantuan tim dalam kelompok, untuk mencapai hasil yang diharapkan bersama. Dengan cara saling memberi motivasi, saling memeriksa jawaban dan saling membantu terhadap kesulitan anggota kelompok serta pengajaran langsung oleh peneliti bagi anggota kelompok dengan kemampuan kurang dari masingmasing kelompok. 
DAFTAR RUJUKAN

Ariyadi, Wijaya. 2010. Matematika Realisitik. Jakarta: Raja Grafindo Persada.

Daryanto, dkk. 2012. Model Pembelajaran Inovatif. Yogyakarta: Gaya Media.

Dewi, Rosmala. 2010. Penelitian Tindakan Kelas. Medan: Pasca Sarjana Unimed.

Hamalik, Oemar. 2001. Proses Belajar Mengajar. Bandung: Yrama Widya.

Herman. 2005. Pengembangan Kurikulum dan Pembelajaran Matematika. IKIP Malang: Malang.

Hudojo, Herman. 2005. Pengembangan Kurikulum dan Pembelajaran Matematika. IKIP Malang: Malang.

Kunandar. 2008. Penelitian Tindakan

Kelas. Jakarta: Raja Grafindo Persada.

Miftahul Huda. 2011. Coopertive Learning Metode, Teknik, Struktur dan Model Penerapan. Yogyakarta: Pustaka Belajar.

Purwanto. 2011. Evaluasi Hasil

Belajar. Yogyakarta: Pustaka Belajar.

Sanjaya. 2008. Perencanaan dan

Desain Sistem Pembelajaran. Jakarta. Kencana Prenada Media Group.
Sardiman. 2009. Interaksi dan Motivasi Belajar Mengajar. Jakarta: Rajagrafindo.

Slavin, Robert E. 2005. Cooperative Learning Teori Riset dan Praktik. Bandung: Nusa Media.

Suprijono. 2012. Cooperative Learning. Yogyakarta: Pustaka Pelajar.

Suwiryo, Yunanda. 2012. Cepat Pintar Kuasai Matematika. Jakarta: Prima Sakti

Trianto. 2010. Mendesain Model Pembelajaran Inovatif Progresif. Jakarta: Kencana. 